\title{
Economic evaluation of the impacts of water quality on fishery production in the Estuary Complex of Santos, São Vicente and Bertioga cities, in southeastern coast of Brazil
}

Avaliação econômica dos impactos ambientais na qualidade da água estuarina

Victor Carrozza Barcellini ${ }^{1}$ (D), Ângela Tavares Paes ${ }^{2}$ (1), Simone Georges El Khouri Miraglia ${ }^{3}$ (1)

\section{A B S T RAC T}

The present study proposes a diagnosis of water quality and fishery production in the Estuarine Complex of Santos, São Vicente, and Bertioga Cities as a requirement for economic valuation of water pollution impacts on fishing production. In the study period (2009-2014), three water quality parameters were identified (dissolved oxygen, total phosphorus, and nitrate), which occurred more frequently in non-conformity with Brazilian water standards, according to reports released by the Environmental Company of São Paulo State (Companhia Ambiental do Estado de São Paulo - CETESB). For data collection of fishery production, data from the monitoring of Institute of Fisheries of Santos City (Instituto de Pesca de Santos) were used, and 15 species were identified with higher occurrence in the study area. The relation between water quality parameters and fishery production was analyzed with mixed linear models, in which significant values for dissolved oxygen parameters, total phosphorus (positive relation), and nitrate (negative relation) were found. Environmental valuation considered only the direct use values (DUV) component of the valuation of fishery production variation in relation to water quality variation. For this purpose, the Marginal Productivity Method (MPM) of the dose-response function was used, which resulted in a range of monetary loss between US\$24,760,550.22 and US\$60,635,978.78. The obtained values represent only a portion of the valuation of economic and environmental loss in the fishing activity (part of DUV). Therefore, economic value calculated is conservative, and although it did not reached the total amount corresponding to all the impacts caused by poor water quality, given the limitations of methods and study period, the obtained values represent the minimum environmental monetary loss.

Keywords: marginal productivity method; direct use values; environmental valuation; water pollution; fishing

\section{RE S U M O}

O estudo propõe um diagnóstico da qualidade da água e da produção pesqueira do Complexo Estuarino de Santos, São Vicente e Bertioga, como subsídio à valoração econômica dos impactos da poluição da água na produção pesqueira. No período do estudo (2009-2014), foram identificados três parâmetros de qualidade da água (oxigênio dissolvido, fósforo total e nitrato) que ocorreram com maior frequência em não-conformidade com as normas brasileiras, segundo os relatórios divulgados pela Companhia Ambiental do Estado de São Paulo (CETESB). Para a coleta de dados da produção pesqueira, foram utilizados os dados do monitoramento do Instituto de Pesca de Santos, sendo identificadas 15 espécies com maior ocorrência na área de estudo. A relação entre os parâmetros de qualidade da água e a produção pesqueira dessas espécies foi analisada através de modelos lineares mistos, resultando em valores significativos para os parâmetros de oxigênio dissolvido, fósforo total (relação positiva) e nitrato (relação negativa). A avaliação ambiental considerou apenas a componente VUD (Valor de Uso Direto) por meio da variação da produção pesqueira em relação à variação da qualidade da água. Para tanto, utilizou-se o Método de Produtividade Marginal (MPM), a partir da função Dose-Resposta, permitindo observar a variação nas perdas monetárias, entre US\$ 24.760.550,22 e US\$ 60.635.978,78. Ressalta-se que os valores obtidos representam apenas uma parcela da valoração da perda econômico-ambiental na atividade de pesca (parte da VUD) e, portanto, a avaliação econômica é subestimada. Cabe apontar que, embora não tenha chegado ao valor total correspondente a todos os impactos ocasionados pela baixa qualidade da água, tendo em vista as limitações dos métodos e período de estudo, entende-se que os valores obtidos representam uma perda monetária ambiental mínima.

Palavras-chave: método de produtividade marginal; valor de uso direto; valoração ambiental; poluição da água; pesca.

\footnotetext{
${ }^{1}$ Master in Environmental Sciences at Universidade Federal de São Paulo (UNIFESP) - Diadema (SP), Brazil.

${ }^{2} \mathrm{PhD}$ in Statistics in the Sector of Applied Statistics of Graduate Studies and Research at UNIFESP - São Paulo (SP), Brazil.

${ }^{3}$ Associate Professor at the Department of Chemical Engineering at UNIFESP - Diadema (SP), Brazil.

Correspondence address: Victor Carrozza Barcellini - Rua São Nicolau, 210, 4o andar - Centro - CEP: 09913-030 - Diadema (SP), Brazil - E-mail: vcbarcellini@hotmail.com
}

Conflicts of interest: the authors declare that there are no conflicts of interest.

Funding: Coordenação de Aperfeiçoamento de Pessoal de Nível Superior (Capes).

Received on: 03/26/2020. Accepted on: 07/22/2020.

https://doi.org/10.5327/Z21769478740 


\section{Introduction}

The interest in the study of ecosystem functions and services to understand the negative impacts of ecosystem degradation on the human populations' well-being and how these changes can affect the ecosystem services' flows is increasing within the scientific community (DE GROOT; WILSON; BOUMANS, 2002; COSTANZA et al., 2014; MARTINEZ-HARMS et al., 2015; ROSA; SÁNCHEZ, 2016; YOSKOWITZ et al., 2017; HACKBART; LIMA; SANTOS, 2017; ENRIQUEZ-ACEVEDO et al., 2018; TANNER et al., 2019; ARMOSKAITE et al., 2020). The analysis of relations, aiming to estimate the impact of an anthropic action on a service's supply, presents a more feasible and viable alternative in practical terms when carried out from a particular ecosystem function directly associated to the service itself (DE GROOT; WILSON; BOUMANS, 2002).

Ecosystem services that are directly related to water can be relevant indicators of disturbances caused by human actions, given that water is the best connectivity element within a landscape, leading to matter and energy flow (GERGEL et al., 2002; HACKBART; LIMA; SANTOS, 2017). Moreover, water reveals a momentary state of disruption, because mobility and its renewal dynamics are intense. In addition, it offers numerous uses for society, such as: raw material in various productive activities, sports, and leisure practices, beyond receiving and recycling matter and even aspects cultural, spiritual experiences and contemplation of nature (ARMOSKAITE et al., 2020).

Throughout the world, coastal waters, widely used for recreation, are also important for the fauna and flora of the marine ecosystem (ARMOSKAITE et al., 2020; FREIRE et al., 2020). Coastal and estuarine ecosystems provide critical services to humans (TOKUNAGA et al., 2020). Waters near the coast are the most productive in the ocean because they receive the contribution of nutrients carried by rivers (MIRANDA; CASTRO; KJERFVE, 2002; ROMERO et al., 2016). The maintenance of these waters' quality is essential to guarantee population's leisure, and to preserve aquatic life and fishing productivity (HUNTINGTON et al., 2017; VISBECK, 2018; ARMOSKAITE et al., 2020).

In Abessa et al. (2018), the authors warn that the chemical pollution status of most of the marine protected areas around the world is unknown. This is aggravated, once many fish and invertebrates present in estuaries and coastal waters are valuable fishing resources, serving as a quick and accessible source of food to humans, forming the basis for the development of a wide range of fisheries. In developing countries, fishing is often the main source of food and income for people living along the coast. Small-scale fisheries are very important food producers, especially because they often bring a higher diversity of fish to the table when compared to the few species that are the focus of industrial fisheries (CANTARELI; RAMIRES; BEGOSSI, 2016; HUNTINGTON et al., 2017). In this way, the direct or indirect introduction of substances and energy by humankind, which can reach high concentration levels, can contaminate estuarine waters leading to adverse effects on living resources, endangering human health, forming obstacles to marine and fishing activities, and reducing its natural attractiveness (MIRANDA; CASTRO; KJERFVE, 2002).

In Brazil, the coastal zone is one of the largest areas under environmental stress due to over-exploitation of natural resources, land use, and low water quality, influenced by the sanitation conditions existing in coastal cities (CETESB, 2016). Many of Brazilian capitals are located on the seafront; in most cases, they do not have enough sanitation infrastructure for their population (ROTH et al., 2016). Thus, dumping domestic sewage on beaches becomes a routine occurrence. This release of untreated domestic effluent makes many uses of aquatic ecosystems unfeasible and may pose serious health threats to local residents and tourists (ROTH et al., 2016; GONÇALVES et al., 2020).

In the Estuarine Complex of Santos, São Vicente, and Bertioga Cities, located along the Brazilian southeastern coast, the industrialization process and development became a source of income, generating migration cycles and potential risks of pollution, considering that the industrial activities of this region were responsible for releasing several potentially toxic substances in the aquatic environment (CETESB, 2016). In addition, the disordered land use and its effects, in terms of sedimentation of the bodies of water, increase in the sedimentation rate and flood, coupled with water pollution due to domestic effluent releases, reflect the currently high eutrophic character of the region, showing no improvement over time (BRAGA et al., 2000; CETESB, 2016; MOREIRA et al., 2018; PERINA et al., 2018; GONÇALVES et al., 2020).

In this context, several studies have used the analysis of chemical parameters to evaluate the alteration of water quality of rivers and lakes (WU et al., 2018; ESCHER et al., 2019; LONGLEY et al., 2019; FONTES; MARANHO; PEREIRA, 2020), and estuaries (ROMERO et al., 2016; SANTOS et al., 2018; DUARTE et al., 2019; FONTES; MARANHO; PEREIRA, 2020; GONÇALVES et al., 2020), where there is a decrease in fish production, associated to the destruction of habitats, overfishing, and water pollution. Additionally, economic values of ecosystem services are an important tool to support ecosystems management (CARRILHO; SINISGALLI, 2018). Several other studies have identified marine and coastal services, estimated their economic value (TADEU; SOSA, 2010; COSTANZA et al., 2014; TANNER et al., 2019; TOKUNAGA et al., 2020), or even estimated their economic and socio-cultural values (QUEIROZ et al., 2017; CARRILHO; SINISGALLI, 2018). Therefore, considering the possibility of increasing the efficiency of environmental management with the complementary use of an economic criterion, the purpose of this study was to economically value the influence of changes in water quality parameters on fishery production and, consequently, local economy.

\section{Materials and Methods}

Study area

The study area is the Estuary Complex of Santos, São Vicente, and Bertioga Cities, which is located in the central coastal region of São 
Paulo State, in Brazil's southeastern coast, covering the estuarine area of São Vicente Island (Santos and São Vicente) and Santo Amaro (Guarujá City), as well as Piaçaguera (Cubatão City) and Bertioga Channel (Figure 1). The region is formed by an extensive plain, limited to the north by Serra do Mar and to the south by the Atlantic Ocean. It has a network of meandering channels, interconnected to the Bay of Santos, with opening to the ocean located to the south, through two main channels that surround São Vicente Island.

The study region presents a great heterogeneity in relation to biotic and anthropogenic abiotic factors, considering the presence of the most important port in Latin America, the port industrial pole with more than 23 industrial complexes, 111 factories, and more than 300 pollution sources. It also experiences transit of large vessels carrying several types of chemicals (DUARTE et al., 2019). Despite all these obstacles to aquatic biota, there are also abundant living resources in the region. They have been commercially exploited for many decades and constitute an important economic activity, especially for the communities of local artisanal fishermen (SEVERINO-RODRIGUES; PITA; GRAÇA-LOPES, 2018).

\section{Data}

Data on surface water quality

Historical data on surface water quality in study areas are scarce. In 2009, the Environmental Company of São Paulo State (Companhia Ambiental do Estado de São Paulo - CETESB) started monitoring the quality of the coastal and estuarine waters of Santos, São Vicente, and Bertioga Cities in 9 samples points: 3 in Santos channel (P01-ST, P02ST and P03-ST), 3 in São Vicente channel (P01-SV, P02-SV and P03$\mathrm{SV}$ ), and 3 in Bertioga channel (P01-B P02-B and P03 -B) (Figure 2).

This monitoring, carried out by CETESB, aims to evaluate water quality with 34 parameters (physical, chemical, and biological), at pre-established sampling points and frequencies. In the study region,
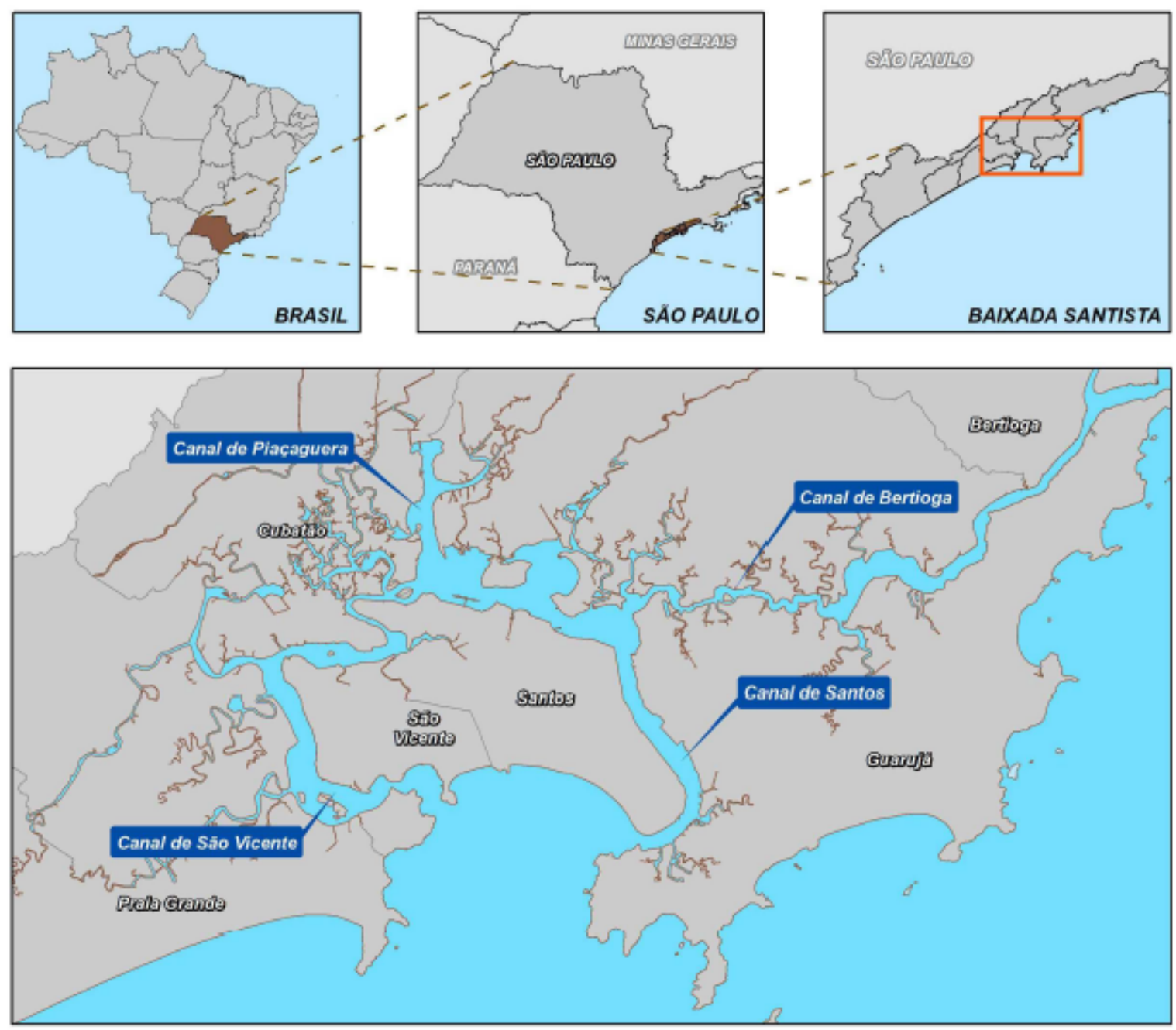

Figure 1 - Geographical location of the study area. 
three parameters (dissolved oxygen - DO, total phosphorus, and nitrate), frequently were in non-conformity with the Brazilian standards established by the National Environment Council in Brazil (CONAMA).

Between 2009 and 2014, 11 semi-annual sampling campaigns were carried out at these 9 points, totaling 99 samples for each parameter. The time series of analyzed parameters in the study period are shown in Figure 3. The Resolution no. 357/05 by CONAMA establishes as a quality condition for DO values greater than $5.0 \mathrm{mg} / \mathrm{L}$, and as a standard condition for total phosphorus those values under $0.124 \mathrm{mg} / \mathrm{L}$, and nitrate, under $0.40 \mathrm{mg} / \mathrm{L}$ (BRASIL, 2005). The parameters systematically decrease along the period in all regions.

\section{Fish community}

The areas with the largest fishing activities in the Estuary Complex (Figure 2) and the main species fished in the region were described in Togni (2013) and used in this study. In all, 15 fish species were identified with higher occurrence in the study area (Table 1).

In order to obtain the fishery production data of these 15 fish species, the annual fishery production monitoring reports of Santos Fishing Institute (IP, 2020) were consulted. Data were tabulated in an Excel spreadsheet. Subsequently, Catch per unit effort (CPUE) of each region (Santos, São Vicente, and Bertioga Cities) were calculated by the total Kg landed divided by Productive Units (fishing boats) (Table 2).
The present study has limited coverage due to the fact of water quality collection having started only in 2009 (resulting in a limited database of water quality indicators), making it difficult to proceed to a sensitivity analysis with scarce data. In this sense, data on fisheries for the same period regarding water quality were used, since such data are available from 1998. If we analyze the historic time series of fisheries data, there is a decreasing trend of fishing stock in the region (Figure 4).

\section{Integrated data analysis: statistical analysis}

Given that water sampling points within regions are similar, and the main observed dependent variable corresponds to the whole region, data from the three points were summarized as means. Therefore, there were 33 sampling units for each parameter (11 semesters and three regions).

The relation between water quality parameters and fishery production (CPUE) was analyzed with mixed linear models, with fish production as a dependent variable, and water quality parameters as independent variables. These models were chosen to consider the correlation between longitudinal measures of the same region. As a first step, simpler models were fitted into only one of the parameters. Those with $\mathrm{p}$ $<0.05$ in the first step were selected to a multiple model. All models included region as a control variable, and the covariance structure was first-order autoregressive. Pearson's correlation was computed to analyze collinearity between independent variables. Assumptions were verified by residual analysis.

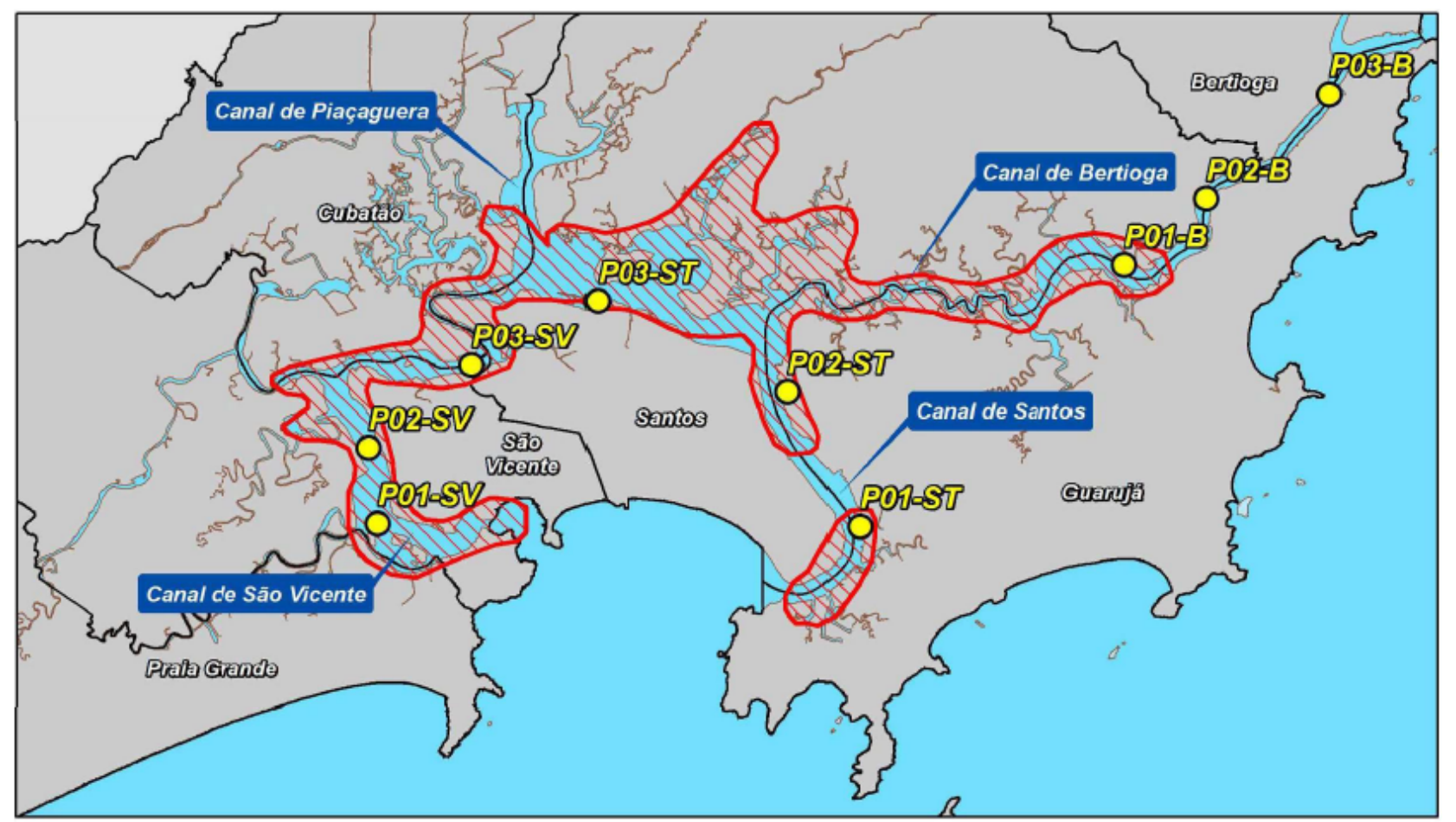

Figure 2 - Location of surface water monitoring points (yellow dots) superimposed on the distribution area of fishing activities identified in Togni, 2013 (hatched in red). 

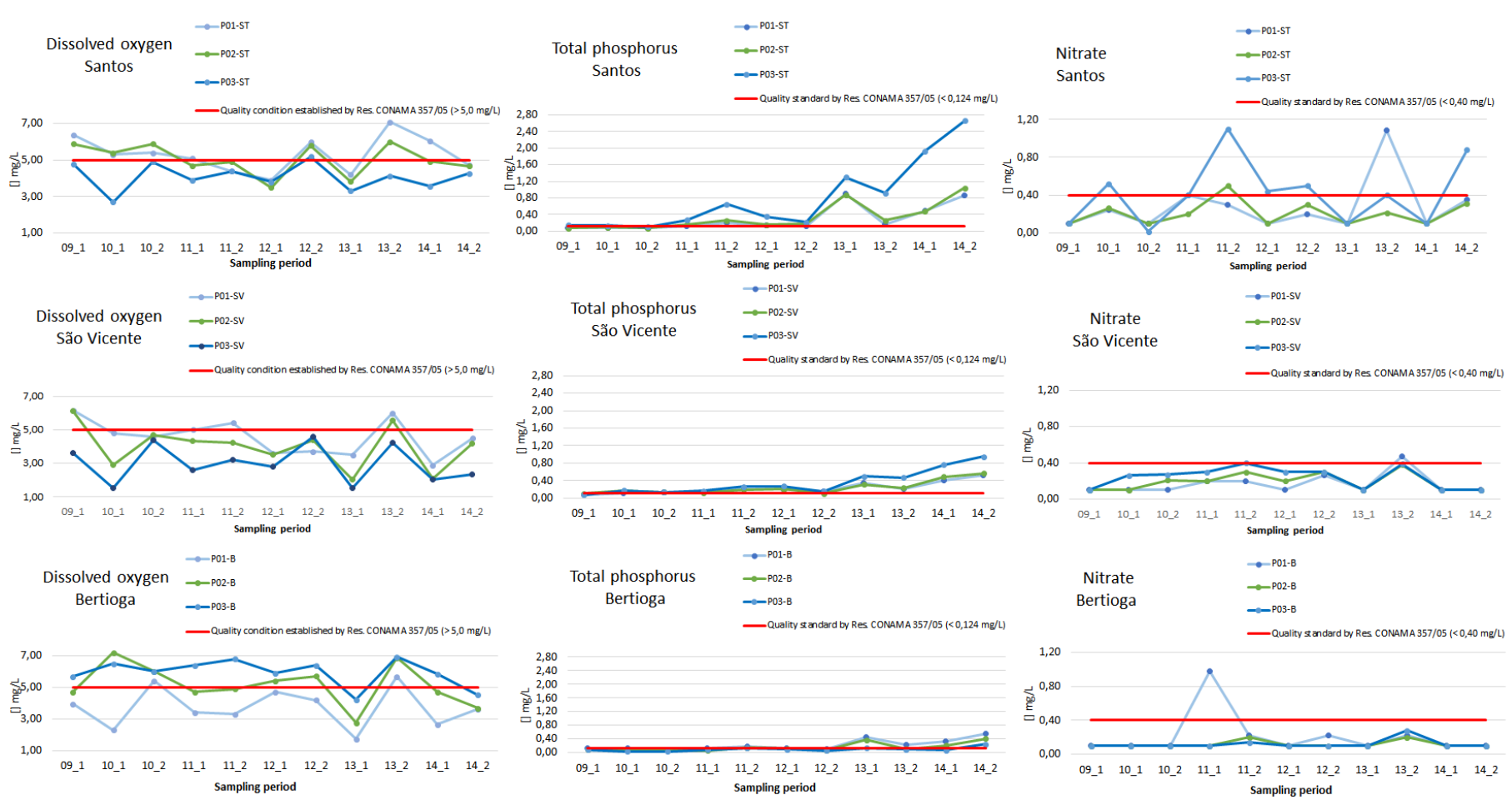

Figure 3 - Results of dissolved oxygen, total phosphorus, and nitrate concentrations in water samples during the 11 semi-annual sampling campaigns, between 2009 and 2014.

From: adapted from CETESB (2016).

Table 1 - List of ichthyofauna species identified with higher occurrence in the study area.

\begin{tabular}{|c|c|}
\hline Groups & Scientific name \\
\hline White mullet & Mugil curema Valenciennes, 1836 \\
\hline Caitipa mojarra & Diapterus rhombeus Cuvier, 1829 \\
\hline Brazilian mojarra & Eugerres brasilianus Cuvier, 1830 \\
\hline Lebranche mullet & Mugil liza Valenciennes, 1836 \\
\hline Whitemouth croaker & Micropogonias furnieri Desmarest, 1823 \\
\hline Largehead hairtail & Trichiurus lepturus Linnaeus, 1758 \\
\hline Snooks & Centropomus undecimalis Bloch, 1792 \\
\hline & Centropomus parallelus Poey, 1860 \\
\hline Sea catfishs & Cathorops spixii Agassiz, 1829 \\
\hline & Genidens barbus Lacepède, 1803 \\
\hline & Genidens genidens Cuvier, 1829 \\
\hline Weakfishs & Cynoscion acoupa Lacepède, 1801 \\
\hline & Cynoscion leiarchus Cuvier, 1830 \\
\hline & Cynoscion microlepidotus Cuvier, 1830 \\
\hline
\end{tabular}

Table 2 - Mean catch per unit effort (CPUE) ratio (kg/units) by study region in the sampled period (2009 to 2014$).$

\begin{tabular}{|l|c|c|c|}
\hline & Santos & São Vicente & Bertioga \\
\hline CPUE $(\mathrm{Kg} /$ units $)$ & 880.27 & 252.29 & 57.73 \\
\hline Standard deviation $( \pm)$ & 124.05 & 74.70 & 23.15 \\
\hline
\end{tabular}




\section{Environmental valuation}

The Marginal Productivity Method (MPM) was used as the method to value the Direct Use Value (DUV) considering the decline in fish production due to the decrease in water quality of the Estuary Complex. In this sense, the MPM method was used to attribute a value to the use of biodiversity by directly relating the quantity or quality of an environmental resource (estuarine water) to the production of another product (fishery production) with a defined market price. The role of environmental resources in the production process will be represented by a Dose-Response function, which relates the level of environmental resource provision to the respective level of production in the market. This function will measure the impact on the productive system, given a marginal variation in the provision of the environmental good or service and, from this variation, an estimation of the economic value of use of estuarine water is estimated (MOTTA, 2006).

The construction of the Dose-Response function involves two basic steps. The first requires the elaboration of a physical function of damage, relating the dose of pollution or degradation to the response of polluted or degraded environmental assets in production. The second corresponds to the formulation of an economic model that measures the financial impact of these changes in the productive process (MAIA; ROMEIRO; REYDON, 2004).
The valuation of the direct use (DUV) of the variation of fishing production in relation to the variation of the estuary's water quality was based on the Dose-Response function presented on Equation 1.

$\mathrm{DUV}=\mathrm{DR}_{\mathrm{CPUE}}{ }^{*}$ Average value ${ }_{\mathrm{CPUE}}$

Caption:

$\mathrm{DR}_{\mathrm{CPUE}}=$ Dose-Response Function of Fishing Production represented by CPUE (Equation 2):

$\mathrm{DR}_{\mathrm{CPUE}}=\mathrm{CI}^{*} \Delta$ (parameter)

Caption:

$\mathrm{CI}=95 \%$ confidence interval (coefficient $|\beta| \pm 1.96 *$ standard error);

$|\beta|=$ linear mixed-effects models coefficient;

$\Delta$ (parameter $)=$ variation of the parameters' maximum and minimum values.

The DR adopted in this study are those that relate to the level of water pollution (Q) that affect water quality (E), which, in turn, affects fish production (Z). Given this DR, damage variation in terms of good variation or environmental service that affects the production of a good can be estimated, in this case fishing.

\section{CPUE (1998 - 2015)}

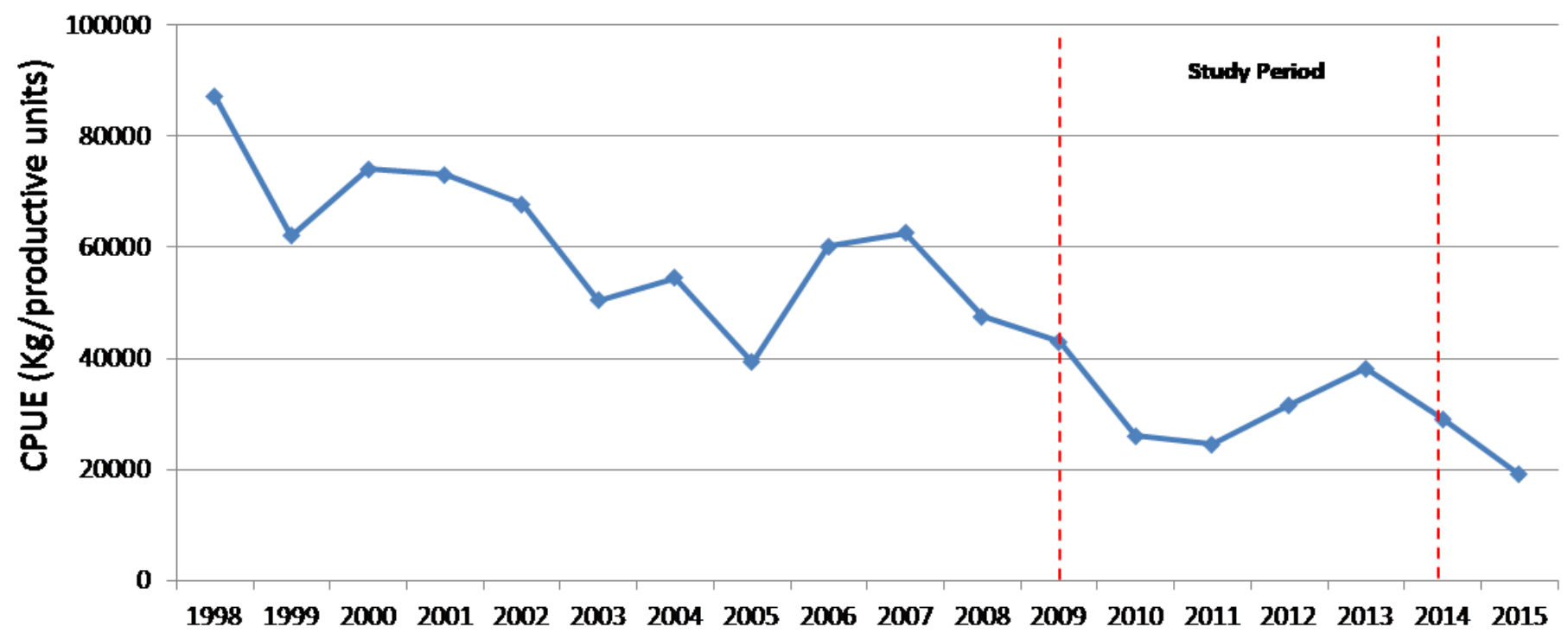

Figure 4 - Catch per unit effort (CPUE) of fishery production of all landed species during the monitoring period conducted by Santos Fishing Institute (1998-2015). Highlighted in the figure, the study period of this paper (2009 to 2014).

Source: adapted from the report by Santos Fishing Institute (IP, 2020). 
Data on water quality were cross-referenced with those of fishery production to verify some relation between those variables throughout the study period. The purpose of MPM was to observe the impact value on fishery production, based on the variation of the Ecosystem Service (Fisheries) to which water quality contributes.

\section{Results}

Integrated analysis of data (statistical analysis)

The relation between water quality parameters and fishery production (CPUE) was analyzed with mixed linear models, with fish production as a dependent variable, and water quality parameters as independent variables. Based on mixed linear models, significant values $(\mathrm{p}<$ 0.05 ) were obtained for dissolved oxygen, total phosphorus (positive relation), and nitrate (negative relation) parameters, demonstrating that these parameters, may negatively influence fish production in the study region at certain concentrations (Table 3).

\section{Environmental valuation}

In order to obtain the Dose-Response (DR) function of CPUE production, according to each of the statistically significant parameters (DO, total phosphorus, and nitrate) the values of each parameter's confidence intervals (CI) were obtained from mixed linear models coefficient modulus, summed, and subtracted $( \pm)$ from the standard confidence coefficient (1.96), and multiplied by the standard error. Table 4 shows the results of confidence interval (CI) and concentration variation $(\Delta)$ of each parameter over the study period.

Applying these results into the formula $\mathrm{DR}_{\mathrm{CPUE}}$ :

Dissolved oxygen:

$\mathrm{DR}_{\mathrm{CPUE}(\text { min.) }}=1,547.12^{*} 5.72=8,849.50$

$$
\begin{aligned}
& \mathrm{DR}_{\mathrm{CPUE}(\text { max.) }}=1,645.38^{\star} 5.72=9,411.58 \\
& \text { Total phosphorus: } \\
& \mathrm{DR}_{\mathrm{CPUE} \mathrm{(min.)}}=4,276.90^{\star} 2.62=1,1205.49 \\
& \mathrm{DR}_{\mathrm{CPUE}(\text { max.) }}=4,429.53^{\star} 2.62=1,1605.37 \\
& \text { Nitrate: } \\
& \mathrm{DR}_{\mathrm{CPUE} \mathrm{(min.)}}=19,602.26^{\star} 1.09=21,366.46 \\
& \mathrm{DR}_{\mathrm{CPUE}(\text { max.) }}=19,882.11^{\star} 1.09=21,671.50
\end{aligned}
$$

This shows a variation between the maximum and minimum DO values in the study period. The impact found on fish production was between $8,849.50$ and 9,411.58 CPUE. For the impacts on total phosphorus, CPUE interval was between 11,205.49 and 11,605.37; for nitrate, between 21,366.46 and 21,671.50.

For appraising damage, fish production values provided by the Institute of Fisheries were used as reference, which were converted into American dollars in the study period and an average value taken by CPUE (Table 5).

As estimated in Table 5, the average value of CPUE obtained in the period was US\$2,797.96. In this way, the values found in the DR function of each of the parameters and the mean value by CPUE resulted in DUV:

- Dissolved oxygen:

$$
\begin{aligned}
& \operatorname{DUV}_{(\text {min.) }}=8,849.50^{*} \text { US\$ 2,797.96 = US\$2 } 24,760,550.22 \\
& \operatorname{DUV}_{\text {(max.) }}=9,411.58^{*} \text { US\$ 2,797.96=US\$26,333,234.51 }
\end{aligned}
$$

- Total phosphorus:

$$
\begin{aligned}
& \operatorname{DUV}_{(\text {min.) }}=11,205.49^{*} \text { US\$ 2,797.96 = US\$ 31,352,508.03 } \\
& \operatorname{DUV}_{(\text {max. })}=11,605.37 * \text { US\$2,797.96 = US\$ 32,471,353.62 } \\
& \operatorname{DUV}_{(\text {min.) }}=21,366.46^{*} \text { US\$2,797.96 }=\text { US\$ 59,782,512.08 } \\
& \operatorname{DUV}_{(\text {max. }}=21,671.50^{*} \text { US\$2,797.96 }=\text { US\$ 60,635,978.78 }
\end{aligned}
$$$$
\text { - Nitrate: }
$$

Table 3 - Results of mixed linear models, relating water quality parameters and CPUE. Estimates adjusted by region.

\begin{tabular}{|l|c|c|c|c|c|}
\hline \multirow{2}{*}{ Parameter } & \multirow{2}{*}{ coef } & Std. Error & \multicolumn{3}{|c|}{ Hypothesis Test } \\
\cline { 3 - 6 } & & & Wald Chi-Square & df & 0.011 \\
\hline Dissolved oxygen & 63.677 & 25.068 & 6.452 & 1.00 & 0.004 \\
\hline Total phosphorus & 111.807 & 38.935 & 8.246 & 1.00 & 1.00 \\
\hline Nitrate & -276.543 & 71.389 & 15.006 & 0.000 \\
\hline
\end{tabular}

Dependent variable: CPUE_SEM; Model: (Intercept), region, Dissolved oxygen, total phosphorus, and nitrate.

Table 4 - Results of confidence intervals and variation of each parameter's maximum and minimum values.

\begin{tabular}{|l|c|c|c|}
\multirow{2}{*}{ Parameter } & \multicolumn{2}{|c|}{ Confidence interval of 95\% (coef $\pm \mathbf{1 , 9 6 *}$ std. error) } & \multirow{2}{*}{ Parameter variation } \\
\cline { 2 - 4 } & Lower & Upper & 5,720 \\
\hline Dissolved oxygen & $1,547.12$ & $1,645.38$ & 2,620 \\
\hline Total phosphorus & $4,276.90$ & $4,429.53$ & 1,090 \\
\hline Nitrate & $19,602.26$ & $19,882.11$ & \\
\hline
\end{tabular}


The values obtained refer to the estimated loss of fishery productivity as a function of each parameter's variation. In relation to the dissolved oxygen, obtained values resulted from monetary loss between US\$24,760,550.22 and US\$ 26,333,234.51 for total phosphorus values between US\$31,352,508.03 (lowest value obtained) and US\$32,471,353.62 (highest value obtained), and as a function of nitrate, loss values between US\$ 59,782,512.08 and US\$ $60,635,978.78)$.

\section{Discussion}

We do not intend to discuss here the source of alteration of dissolved oxygen in the study area's water, or even the origin of excess nutrients (total phosphorus and nitrate) in the aquatic environment of the study region, even considering its importance. However, based on the obtained results, the region presents high concentrations of these nutrients in its surface water, introduced by anthropic sources, that lead to a hypereutrophic state of aquatic ecosystems. This contribution of higher concentrations of nutrients to the estuary may be related to the emission of effluents (domestic and industrial); activities related to the port (such as accidental spills of substances in the aquatic environment, transport of solid waste, generation of liquid effluents, and dredging); and the port industrial center, which has several large companies. This assertion is not only based on data observed in research, but also on information generated by several authors and papers carried out in the study region, which also considered surface water and sediment. (BRAGA et al., 2000; MOREIRA et al., 2018; PERINA et al., 2018; DUARTE et al., 2019; GONÇALVES et al., 2020).

All these changes in water quality parameters can lead to loss, in an ecological analysis based on the Ecosystem Function, Nutrient Regulation, and Ecosystem Services derived from this function, such as primary production, biodiversity maintenance, biogeochemical cycles, habitat impairment, and others (DE GROOT; WILSON; BOUMANS, 2002). The number of ecosystem services affected shows the high degree of dependence between environmental variables, as well as the high degree of complexity underlying the ecosystem analyzed.

The relation between water quality parameters and fishery production was analyzed with mixed linear models. Significant values were obtained for dissolved oxygen, total phosphorus, and nitrate parameters, indicating a relation between these parameters and fish production. In the analysis, significant values were obtained for dissolved oxygen, total phosphorus (positive relation), and nitrate (negative relation), that is, the increase in dissolved oxygen concentration in water can positively favor fish production, whereas a high concentration of nitrate can negatively influence the region's fishing productivity. For the total phosphorus parameter, caution is required to analyze this positive relation, given that this parameter is an essential nutrient for many life forms. At certain concentrations,

Table 5 - Fisheries Production and Marketed Values, Dollarized and Average Values per CPUE. (Average quotation of the US dollar versus the Brazilian real in: http://economia.uol.com.br/cotacoes/cambio/dolar-comercial-estados-unidos/?historico).

\begin{tabular}{|c|c|c|c|c|c|c|c|}
\hline Period & Kg & $\begin{array}{c}\text { No. } \\
\text { productive } \\
\text { units }\end{array}$ & CPUE & Value in the period & $\begin{array}{c}\text { Average } \\
\text { dollar value } \\
\text { in the period }\end{array}$ & Dollarized value & $\begin{array}{c}\text { Average value } \\
\text { US\$ / CPUE }\end{array}$ \\
\hline $2009\left(1^{\mathrm{st}}\right)$ & $1,368.599 .2$ & 1429 & 957.732 & $\mathrm{R} \$ 4,716.740 .92$ & 1.95 & $\$ 2,418.841 .50$ & $\$ 2,525.59$ \\
\hline $2010\left(1^{\mathrm{st}}\right)$ & $1,079.619 .5$ & 1316 & 820.380 & $\mathrm{R} \$ 5,419.894 .38$ & 1.81 & $\$ 2,994.416 .78$ & $\$ 3,650.04$ \\
\hline $2010\left(2^{\text {nd }}\right)$ & $1,671.983 .6$ & 2026 & 825.263 & $\mathrm{R} \$ 4,074.728 .00$ & 1.68 & $\$ 2,425.433 .33$ & $\$ 2,938.98$ \\
\hline $2011\left(1^{\mathrm{st}}\right)$ & $1,156.393$ & 1305 & 886.125 & $\mathrm{R} \$ 3,695.272 .05$ & 1.59 & $\$ 2,324.070 .47$ & $\$ 2,622.73$ \\
\hline $2011\left(2^{\text {nd }}\right)$ & $1,327.106 .2$ & 1940 & 684.075 & $\mathrm{R} \$ 3,899.926 .16$ & 1.82 & $\$ 2,142.816 .57$ & $\$ 3,132.43$ \\
\hline $2012\left(1^{\mathrm{st}}\right)$ & $941,559.2$ & 1392 & 676.407 & $\mathrm{R} \$ 4,426.245 .63$ & 2.05 & $\$ 2,159.144 .21$ & $\$ 3,192.08$ \\
\hline $2012\left(2^{\text {nd }}\right)$ & $1,404.440 .4$ & 1379 & $1,018.448$ & $\mathrm{R} \$ 5,745.358 .59$ & 2.09 & $\$ 2,748.975 .40$ & $\$ 2,699.18$ \\
\hline $2013\left(1^{\mathrm{st}}\right)$ & $980,711.1$ & 1036 & 946.632 & $\mathrm{R} \$ 4,144.875 .30$ & 2.16 & $\$ 1,918.923 .75$ & $\$ 2,027.11$ \\
\hline $2013\left(2^{\text {nd }}\right)$ & $1,318.071 .3$ & 1489 & 885.206 & $\mathrm{R} \$ 7,206.390 .12$ & 2.35 & $\$ 3,066.548 .99$ & $\$ 3,464.22$ \\
\hline $2014\left(1^{\text {st }}\right)$ & $1,128.796 .8$ & 1053 & $1,071.982$ & $\mathrm{R} \$ 5,304.501 .73$ & 2.20 & $\$ 2,411.137 .15$ & $\$ 2,249.23$ \\
\hline \multirow[t]{3}{*}{$2014\left(2^{\text {nd }}\right)$} & $1,166.689 .0$ & 1281 & 910.764 & $\mathrm{R} \$ 5,410.138 .43$ & 2.61 & $\$ 2,072.849 .97$ & $\$ 2,275.95$ \\
\hline & & & & & & Total & $\$ 30,777.54$ \\
\hline & & & & & & Average & $\$ 2,797.96$ \\
\hline
\end{tabular}

$\left(1^{\text {st }}\right)$ : first semester $/\left(2^{\text {nd }}\right)$ : second semester 
it can enrich the environment and favor the increase of the algal community, which can positively influence the diet of some specimens of ichthyofauna (SILVA-NETO, 2012). However, at higher concentrations, it becomes toxic to the aquatic environment, which can lead to a state of eutrophication (THOMAS; CALLAN, 2015; LONGLEY et al., 2019; ROCHA; MESQUITA; LIMA NETO, 2019). Thus, further studies on the dose-response effects of this parameter in aquatic environments, in addition to fauna, are needed to evaluate the threshold between positive and negative effects, according to their concentration.

Regarding economic analysis, environmental assessment was applied to the Fisheries Ecosystem Service associated to Food with the evaluation of impacts resulting from the low water quality condition on this Ecosystem Fisheries Service. Although the total value corresponding to all the impacts caused by the poor water quality was not reached, considering the limitations of the methods and time of study, establishing statistical associations and relations between the variation of water quality and fish production of the selected fish species was possible. With the dose-response relations, variation in the marginal productivity of fishery production was reached. This allowed the variation in monetary loss as a function of the variation of water quality parameters, during the study period, to be observed.

Determining the dose-response relations between estuarine water quality and fish production is a pioneering effort in the study region, as well as the use of this methodology for the integrated analysis of results. This is the first study to establish a relation between water pollution and fishery production; additionally, it estimates an economic value on the ecosystem service deterioration. Our results are preliminary and have limitations, such as the non-guarantee about possible non-observed confounders. Besides that, the aim of the present study was not to establish rules nor to determine a fixed economic valuation to be adopted. Therefore, this analysis is expected to be feasible for replication in other environments to allow a comparative analysis, as well as a temporal evolution. Seen that, this approach consists of an important tool for environmental monitoring, in view of the possibility of increasing the efficiency of environmental management with the complementary use of an economic criterion.

In this sense, economic valuation of the impact obtained presented values of monetary loss that varied between US\$ $24,760,550.22$ and US\$ $60,635,978.78$ in the study period, considering the parameters analyzed. These values represent a portion of the value of environmental loss in the fishing activity in the region, caused by the decrease in water quality, evaluated by dissolved oxygen, phosphorus, and nitrate parameters. Therefore, we assume that this economic valuation is underestimated. We encourage further studies to enrich the valuation approach proposed herein. Howev- er, we consider it a first value for discussion and improvement for the environmental management of the studied estuarine complex.

In other studies, such as in Costanza et al. (2014), loss of ecosystem services worldwide between 1997 and 2011 is estimated to have ranged from US\$ 4.3 to US\$ 20.2 trillion per year. Yet, they believe that these estimates are conservative, as well as the values obtained in this paper, given the difficulty in evaluating all ecological interactions.

Tanner et al. (2019) presented the first economic valuation of multiple ecosystem services for Ecuador, using Galapagos mangroves as a case study. They focused on three ecosystem services of high value and policy relevance: carbon storage, support for smallscale fisheries, and mangrove-based tourism. Their data suggested that over 778,000 metric tons of carbon are stored in Galapagos mangroves, with mean belowground carbon being $211.03 \pm 179.65 \mathrm{Mg}$ $\mathrm{C} /$ ha, valued at $\$ 2,940 /$ ha or $\$ 22,838 / \mathrm{ha}$, depending on the valuation methodology. They identified mangrove-dependent fish targeted by the local finfish fishery, with net benefits of $\$ 245 /$ ha, making this fishery the second most profitable in the Archipelago. The value of mangrove-based recreation was estimated at $\$ 16,958 / \mathrm{ha}$, contributing with $\$ 62$ million to the industry.

In Brazil, economic valuation of environmental damage is not frequent. Tadeu and Sosa (2010), with the Marginal Productivity Method, observed economic and environmental impacts resulting from the reopening of Valo Grande on the Cananéia-Iguape-Paranaguá Estuary-Lagunar Complex (CEL-CIP) located on the southern coast of São Paulo State. With data on fishing and based on the analysis of water quality, direct relations between the flow of the river Ribeira de Iguape and the region's fishery production were found. A correlation between the "flow" variation and variation in the fishery production of some species of the local ichthyofauna were observed. In this sense, economic valuation of the impact resulted in a marginal variation in economic gain, of US\$ 641.03 for each variation of $1.0 \mathrm{~m}^{3} / \mathrm{s}$ of the flow.

Carrilho and Sinisgalli (2018) identified and evaluated, with economic and socio-cultural perspectives, the ecosystem services provided by Araçá Bay (in the southeastern coast of Brazil). The sum of the estimated (annual) economic value of the ecosystem services in 2014 was US\$ $340,610.29$, and the most valued service was effluent depuration. In turn, the food supply service was the most important in the socio-cultural valuation. The authors also point out that, although economic and socio-cultural values were able to reveal certain contributions of Araçá Bay to humans' well-being, they couldn't represent all of them, because the Bay's contribution to the subsistence of local families.

Environmental economic valuation of the impact of the alteration of water quality on the supply of the Ecosystem Service Fisheries presents limitations. It considered only a few species (15), 
culminating in a reductionist analysis, which disregarded a series of other factors (ecological and human) that are important to evaluate or assess environmental impacts.

An aspect to be considered is the variability in fisheries production over time, due to changes in global ocean cycles or other factors that could influence productivity. Some studies concerning fisheries production and operational variables in commercial fishery in São Paulo State (ROLIM; SILVA, 2018; SILVA et al., 2019) warn about the possibility of production variations due to overfishing. Togni (2013) show that fisheries in the Santos Estuarine present a high degree of technique diversity applied to capture. This diversification may mean an alternative to supply the diminish of both numeric and biomass abundance related to pollution and other resources aimed by fishers. Artisanal and recreational fisheries that use small- or medium-sized boats are performed with no employment bond. As shown in estuaries from São Paulo State (BARCELLINI et al., 2013; MOTTA; MENDONÇA; MORO, 2016; FREIRE et al., 2020; SILVA et al., 2020), these studies demonstrate the need for conducting long-term studies about these activities to gather more knowledge of this dynamics and its interactions with other activities that support resources management.

As previously mentioned, this is an exploratory pioneer study, which presents some limitations concerning the beginning of data collection, their frequency, and quality. In this sense, once data collection started in 2009 in a 6-month basis, some discrepancies may be found due to the season of the year, such as the associated meteorological conditions of the period of the collected sample's year. Moreover, additional studies must be conducted to identify these patterns and enable a confirmation of this behavior.

In addition, obtaining a larger number of samples and analyzes would be interesting, so that nutrient behavior and the influence of water quality on fish production could be observed in depth. Another aspect to consider is the season of the year in which collections were made, because there may be differences in-between dry and humid seasons, mainly in relation to nutrient contents carried to the estuary, as well as particulate matter in suspension.

Nonetheless, as shown, establishing the influence of the parameters analyzed in fish production in a statistical way was possible. Thus, the valuation obtained in this paper is considered a first value to be discussed and improved for the purposes of environmental management of the studied estuarine complex. Other estimates that represent the other environmental values, such as indirect and exis- tence values should be considered for appropriate management and environmental valuation, aiming at improving the understanding of how ecological changes have consequences on economic activities.

\section{Conclusion}

Based on the survey of historical data on water quality, a reduction in water quality due to the increase in concentrations of some of parameters was observed, leading to a state of anthropic hyper eutrophication. The contribution of higher concentrations of nutrients to the estuary is related to the emission of domestic and industrial effluents, and activities related to the port and the industrial pole.

In relation to the main fish species landed in the region, 15 species were identified with higher occurrence. The highest values of catches per unit of effort (CPUE) were observed in Santos City. When relating data on water quality to data on fishery production, and using mixed linear models, significant values were obtained for dissolved oxygen, total phosphorus (positive relation), and nitrate (negative relation).

Data show that environmental degradation of the impacts caused by changes in water quality directly influences fish productivity. Besides that, considering only the study period, these changes have resulted in an estimated monetary loss of US $\$ 24,760,550.22$ to US\$ $60,635,978.78$. Therefore, from an economic point of view, the reduction of water quality may cause negative impacts on the region's fishing productivity. Consequently, economic impacts due to changes in this environmental matrix can also be seen.

Hence, the values obtained in this study demonstrate a minimum environmental monetary loss, because, even underestimated, these values reflect how the pollution of these aquatic environments can lead to monetary loss and negative externalities to the population and the environment. The achievement of a dose-response relation and this economic-environmental result are important factors to sensitize public managers in decision-making to promote initiatives for the prevention and environmental improvement of this ecosystem.

Finally, this study has the pioneering character of obtaining a dose-response function of the estuary's quality in the region, besides the application of the methodology of environmental economic valuation to estimate damage to the aquatic environment. This also intends to contribute to the discussion and improve of the use of this tool for environmental management of water resources in Brazil.

\section{Contribution of authors:}

Barcellini, V.C.: Conceptualization, Methodology, Data collect, Validation, Formal analysis, Investigation, Data curation, Writing - original draft, Writing review and editing. Miraglia, S.G.E.K.: Conceptualization, Validation, Writing — review. Paes, Â.T.: Statistical analysis, Writing — review. 


\section{References}

ABESSA, D.M.S.; ALBUQUERQUE, H.C.; MORAIS, L.G.; ARAÚJO, G.S.; FONSECA, T.G.; CRUZ, A.C.F.; CAMPOS, B.G.; CAMARGO, J.B.D.A.; GUSSO-CHOUERI, P.K.; PERINA, F.C.; CHOUERI, R.B.; BURUAEM, L.M. Pollution status of marine protected areas worldwide and the consequent toxic effects are unknown. Environmental Pollution, v. 243, part B, p. 450-1459, 2018. https://doi.org/10.1016/j.envpol.2018.09.129

ARMOSKAITE, A.; PURIN̦A, I.; AIGARS, J.; STRAĶE, S.; PAKALNIETE, K.; FREDERIKSEN, P.; SCHRODER, L.; HANSEN, H.S. Establishing the links between marine ecosystem components, functions and services: An ecosystem service assessment tool. Ocean \& Coastal Management, v. 193, 105229, 2020. https://doi.org/10.1016/j.ocecoaman.2020.105229

BARCELLINI, V.C.; MOTTA, F.S.; MARTINS, A.M.; MORO, P.S. Recreational anglers and fishing guides from an estuarine protected area in southeastern Brazil: Socioeconomic characteristics and views in fisheries management. Ocean \& Costal Management, v. 76, p. 23-29, 2013. https://doi.org/10.1016/j. ocecoaman.2013.02.012

BRAGA, E.S.; BONETTI, C.V.D.H.; BURONE, L.; BONETTI FILHO, J. Eutrophication and bacterial pollution caused by industrial and domestic wastes at the Baixada Santista estuarine system - Brazil. Marine Pollution Bulletin, v. 40, n. 2, p. 165-173, 2000. https://doi.org/10.1016/S0025326X(99)00199-X

BRASIL. Conselho Nacional do Meio Ambiente (CONAMA). Resolução no 357, de 17 de março de 2005. Dispõe sobre a classificação dos corpos de água e diretrizes ambientais para o seu enquadramento, bem como estabelece as condições e padrões de lançamento de efluentes, e dá outras providências. Diário Oficial da União, Brasília, n. 53, p. 58-63, 18 mar. 2005. Available from: <http:// www.mma.gov.br/port/conama/res/res05/res35705.pdf $>$. Accessed on: March $17,2020$.

CANTARELI, C.V.; RAMIRES, M.; BEGOSSI, A. The Socio-ecological system of selected Brazilian small-scale fisheries. Unisanta Bioscience, v. 5, n. 5, p. 382-394, 2016

CARRILHO, C.D.; SINISGALLI, P.A.A. Contribution to Araçá Bay management: The identification and valuation of ecosystem services. Ocean \& Coastal Management, v. 164, p. 128-135, 2018. https://doi.org/10.1016/j. ocecoaman.2018.03.023

COMPANHIA AMBIENTAL DO ESTADO DE SÃO PAULO (CETESB). Relatório de qualidade das águas superficiais no Estado de São Paulo 2015 Parte 2: águas salinas e salobras. São Paulo: Cetesb, 2016. Série Relatórios. 164 p.

COSTANZA, R.; DE GROOT, R.; SUTTON, P.; PLOEG, S.V.D.; ANDERSON, S.J.; KUBISZEWSKI, I.; FARBER, S.; TURNER, R.K. Changes in the global value of ecosystem services. Global Environmental Change, v. 26, p. 152-158, 2014. https://doi.org/10.1016/j.gloenvcha.2014.04.002

DE GROOT, R.; WILSON, M.A.; BOUMANS, R.M.J. A typology for the classification, description and valuation of ecosystem functions, goods and services. Ecological Economics, v. 41, n. 3, p. 393-408, 2002. https://doi. org/10.1016/S0921-8009(02)00089-7

DUARTE, L.F.A.; MORENO, J.B.; CATHARINO, M.G.M.; MOREIRA, E.G.; TROMBINI, C.; PEREIRA, C.D.S. Mangrove metal pollution induces biological tolerance to $\mathrm{Cd}$ on a crab sentinel species subpopulation. Science of The Total Environment, v. 687, p. 768-779, 2019. https://doi.org/10.1016/j. scitotenv.2019.06.039

ENRIQUEZ-ACEVEDO, T.; BOTERO, C.M.; CANTERO-RODELO, R.; PERTUZ, A.; SUAREZ, A. Willingness to pay for Beach Ecosystem Services: The case study of three Colombian beaches. Ocean \& Coastal Management, v. 161, p. 96-104, 2018. https://doi.org/10.1016/j.ocecoaman.2018.04.025
ESCHER, M.A.S.; AMÉRICO-PINHEIRO, J.H.P.; TORRES, N.H.; FERREIRA, L.F.R. A problemática ambiental da contaminação dos Recursos Hídrico por Fármacos. Revista Brasileira de Ciências Ambientais, n. 51, p. 141-148, 2019. https://doi.org/10.5327/Z2176-947820190469

FONTES, M.K.; MARANHO, L.A.; PEREIRA, C.D.S. Review on the occurrence and biological effects of illicit drugs in aquatic ecosystems. Environmental Science and Pollution Research, v. 27, p. 30998-31034, 2020. https://doi.org/10.1007/s11356-020-08375-2

FREIRE, K.M.F.; BELHABIB, D.; ESPEDIDO, J.; HOOD, L.; KLEISNER, K.; LAM, V.; MACHADO, M.; MENDONÇA, J.T.; MEEUWIG, J.; MORO, P.S.; MOTTA, F.S.; PALOMARES, M.L.D.; SMITH, N.; TEH, I.C.L.; ZELLER, D.; ZYLICH, K.; PAULY, D. Estimating global catches of marine recreational fisheries. Frontiers in Marine Science, v. 7, p. 1-18, 2020. https://doi. org/10.3389/fmars.2020.00012

GERGEL, S.E.; TURNER, M.G.; MILLER, J.R.; MELACK, J.M.; STANLEY, E.H. Landscape indicators of human impacts to riverine systems. Aquatic Sciences, v. 64, p. 118-128, 2002. https://doi.org/10.1007/s00027-002-8060-2

GONÇALVES, A.R.N.; MARINSEK, G.P.; ABESSA, D.M.S.; MARI, R.B. Adaptative responses of myenteric neurons of Sphoeroides testudineus to environmental pollution. Neurotoxicology, v. 76, p. 84-92, 2020. https://doi. org/10.1016/j.neuro.2019.10.008

HACKBART, V.C.S.; LIMA, G.T.N.P.; SANTOS, R.F. Theory and practice of water ecosystem services valuation: Where are we going? Ecosystem Services, v. 23, p. 218-227, 2017. https://doi.org/10.1016/j.ecoser.2016.12.010

HUNTINGTON, H.P.; BEGOSSI, A.; FOX GEARHEARD, S.; KERSEY, B.; LORING, P.A.; MUSTONEN, T.; PAUDEL, P.K.; SILVANO, R.A.M.; VAVE, R. How small communities respond to environmental change: patterns from tropical to polar ecosystems. Ecology and Society, v. 22, n. 3, p. 9-22, 2017.

INSTITUTO DE PESCA (IP). Programa de Monitoramento da Atividade Pesqueira Marinha e Estuarina do Instituto de Pesca. São Paulo: IP, 2020. Available from: $<\mathrm{http}: / / \mathrm{www}$.propesq.pesca.sp.gov.br/relatorio/30 $>$. Accessed on: March 17, 2020.

LONGLEY, K.R.; HUANG, W.; CLARK, C.; JOHNSON, E. Effects of nutrient load from St. Jones River on water quality and eutrophication in Lake George, Florida. Limnologica, v. 77, 125687, 2019. https://doi.org/10.1016/j. limno.2019.125687

MAIA, A.G.; ROMEIRO, A.R.; REYDON, B.P. Valoração de recursos ambientais: metodologias e recomendações. Campinas: IE/UNICAMP, 2004. $39 \mathrm{p}$.

MARTINEZ-HARMS, M.J.; BRYAN, B.A.; BALVANERA, P.; LAW, E.A.; RHODES, J.R.; POSSINGHAM, H.P.; WILSON, K.A. Making decisions for managing ecosystem services. Biological Conservation, v. 184, p. 229-238, 2015. https://doi.org/10.1016/j.biocon.2015.01.024

MIRANDA, L.B.; CASTRO, B.M.; KJERFVE, B. Princípios de oceanografia física de estuários. São Paulo: Editora da Universidade de São Paulo, 2002. 411 p.

MOREIRA, L.B.; CAMARGO, J.B.D.A.; MARQUES, B.B.; MARTINS, C.C.; ABESSA, D.M.S. Multiple lines of evidence of sediment quality in an urban Marine Protected Area (Xixová-Japuí State Park, SP, Brazil). Environmental Science and Pollution Research, v. 26, p. 4605-4617, 2018. https://doi. org/10.1007/s11356-018-3941-7

MOTTA, F.S.; MENDONÇA, J.T.; MORO, P.S. Collaborative assessment of recreational fishing in a subtropical estuarine system: a case study with fishing guides from south-eastern Brazil. Fisheries Management and Ecology, v. 23, n. 3-4, p. 291-302, 2016. https://doi.org/10.1111/fme.12172 
MOTTA, R.S.D. Economia Ambiental. Rio de Janeiro: Editora FGV, 2006. 228 p.

PERINA, F.C.; TORRES, R.J.; MOZETO, A.A.; NASCIMENTO, M.R.L.; ABESSA, D.M.S. Sediment quality assessment of the tributaries of the SantosSão Vicente Estuarine System - Brazil. Ecotoxicology and Environmental Contamination, v. 13, n. 2, p. 25-38, 2018. https://doi.org/10.5132/ eec.2018.02.05

QUEIROZ, L.S.; ROSSI, S.; CALVET-MIR, L.; RUIZ-MALLÉN, I.; GARCÍABETORZ, S.; SALVÀ-PRAT, J.; MEIRELES, A.J.A. Neglected ecosystem services: Highlighting the socio-cultural perception of mangroves in decisionmaking processes. Ecosystem Services, v. 26, part A, p. 137-145, 2017. https:// doi.org/10.1016/j.ecoser.2017.06.013

ROCHA, S.M.G.; MESQUITA, J.B.F.; LIMA NETO, I.E. Análise e modelagem das relações entre nutrientes e fitoplâncton em reservatórios do Ceará. Revista Brasileira de Ciências Ambientais, n. 54, p. 134-147, 2019. https://doi. org/10.5327/Z2176-947820190536

ROLIM, F.A.; SILVA, A.O.A. Influence of environmental and operational variables in commercial fishery landings: The case of pair trawlers in southeastern Brazil. Regional Studies in Marine Science, v. 24, p. 133-142, 2018. https://doi.org/10.1016/j.rsma.2018.08.007

ROMERO, E.; LE GENDRE, R.; GARNIER, J.; BILLEN, G.; FISSON, C.; SILVESTRE, M.; RIOU, P. Long-term water quality in the lower Seine: Lessons learned over 4 decades of monitoring. Environmental Science \& Policy, v. 58, p. 141-154, 2016. https://doi.org/10.1016/j.envsci.2016.01.016

ROSA, J.C.S.; SÁNCHEZ, L.E. Advances and challenges of incorporating ecosystem services into impact assessment. Journal of Environmental Management, v. 180, p. 485-492, 2016. https://doi.org/10.1016/j.

jenvman.2016.05.079

ROTH, F.; LESSA, G.C.; WILD, C.; KIKUCHI, R.K.P.; NAUMANN, M.S. Impacts of a high-discharge submarine sewage outfall on water quality in the coastal zone of Salvador (Bahia, Brazil). Marine Pollution Bulletin, v. 106, n. 1-2, p. 43-48, 2016. https://doi.org/10.1016/j.marpolbul.2016.03.048

SANTOS, T.A.; BOMFIM, T.M.; SILVA, A.F.; SILVA, A.G.; BANDEIRA, M.L.S.F.; JESUS, R.M.; NASCIMENTO, L.D. Determinação de metais em um sistema estuarino: Laguncularia Racemosa como um potencial indicador de contaminação. Revista Brasileira de Ciências Ambientais, n. 49, p. 51-65, 2018. https://doi.org/10.5327/10.5327/Z2176-947820180352

SEVERINO-RODRIGUES, E.; PITA, J.B.; GRAÇA-LOPES, R. Artisan swimming crabs fishery (Crustacea, Decapoda, Portunidae) in the estuary of Santos and São Vicente, São Paulo State, Brazil. Boletim do Instituto de Pesca, v. 27, n. 1, p. 7-19, 2018.

SILVA, A.O.A.; CARNEIRO, M.H.; MENDONÇA, J.T.; BASTOS, G.C.C.; MIRANDA, L.V.; RIBEIRO, W.R.; SANTOS, S. Produção Pesqueira Marinha e Estuarina do Estado de São Paulo. Informe Pesqueiro de São Paulo, v. 112, p. $1-21,2019$

SILVA, L.M.C.; MACHADO, I.C.; TUTUI, S.L.S.; TOMÁS, A.R.G. Local ecological knowledge (LEK) concerning snook fishers on estuarine waters: Insights into scientific knowledge and fisheries management. Ocean \& Coastal Management, v. 186, 105088, 2020. https://doi.org/10.1016/j. ocecoaman.2019.105088

SILVA-NETO, A.G. Alimentação da tainha Mugil curema (Perciformes: Mugilidae) e caracterização ambiental do Estuário do Rio Paraíba do Norte. 74f. Dissertation (Mestrado em Ecologia) - Universidade Estadual da Paraíba, Campina Grande, 2012.

TADEU, N.D.; SOSA, P.R.B. Valoração econômico-ecológica dos impactos decorrentes da existência do Valo Grande sobre o Complexo Estuarino Lagunar Cananéia-Iguape-Paranaguá (CEL-CIP), Litoral Sul de São Paulo/Brasil. 141f. Dissertation (Mestrado em Gestão Ambiental) - Universidade de São Paulo, São Paulo, 2010.

TANNER, M.K.; MOITY, N.; COSTA, M.T.; JARRIN, J.R.M.; ABURTOOROPEZA, O.; SALINAS-DE-LEÓN, P. Mangroves in the Galapagos: Ecosystem services and their valuation. Ecological Economics, v. 160, p. 12-24, 2019. https://doi.org/10.1016/j.ecolecon.2019.01.024

THOMAS, J.M.; CALLAN, S.J. Economia Ambiental: Fundamentos, políticas e aplicações. Tradução de Antônio Claudio Lot, Marta Reyes Gil Passos. São Paulo: Cengage Learning, 2015. 556 p.

TOGNI, G.L. Atividades Pesqueiras no Complexo Estuarino de Santos e São Vicente, São Paulo - Brasil. 72f. Dissertation (Mestrado em Aquicultura e Pesca) - Instituto de Pesca, Santos, 2013.

TOKUNAGA, K.; SUGINO, H.; NOMURA, H.; MICHIDA, Y. Norms and the willingness to pay for coastal ecosystem restoration: A case of the Tokyo Bay intertidal flats. Ecological Economics, v. 169, 106423, 2020. https://doi. org/10.1016/j.ecolecon.2019.106423

VISBECK, M. Ocean science research is key for a sustainable future. Nature Communications, v. 9, p. 690-694, 2018. https://doi.org/10.1038/s41467-01803158-3

WU, Z.; WANG, X.; CHEN, Y.; CAI, Y.; DENG, J. Assessing river water quality using water quality index in Lake Taihu Basin, China. Science of the Total Environment, v. 612, p. 914-922, 2018. https://doi.org/10.1016/j. scitotenv.2017.08.293

YOSKOWITZ, D.; CAROLLO, C.; POLLACK, J.B.; SANTOS, C.; WELDER, $\mathrm{K}$. Integrated ecosystem services assessment: Valuation of changes due to sea level rise in Galveston Bay, Texas, USA. Integrated Environmental Assessment and Management, v. 13, n. 2, p. 431-443, 2017. https://doi. org/10.1002/ieam.1798 